\title{
DYNAMICS OF AN ORTHOTROPIC RAILWAY BRIDGE IN THE LIGHT OF EUROPEAN STANDARDS
}

\author{
A. ZBICIAK ${ }^{1}$, R. OLESZEK ${ }^{2}$, R. MICHALCZYK ${ }^{3}$
}

\begin{abstract}
The paper presents selected aspects of dynamic numerical simulations of an orthotropic steel railway bridge loaded by high-speed trains. The model of moving loads was adopted in accordance with the models set out in the applicable standards. The current European code requirements are referred in which the computer calculations of the dynamic response of the structure are the basis for assessing the suitability of the structure to carry high-speed rail traffic $(v>160 \mathrm{~km} / \mathrm{h})$. In this research the calculations are based on the author's method of generating traffic loads in Abaqus FEM environment. It is emphasized in the paper that in most commercial FEM codes (including Abaqus), moving loads are not implemented in modules responsible for defining of loads. The author's approach to this issue allowed to obtain results confirming its adequacy. In the longer term, the authors will develop a plan to adapt this algorithm in order to generate traffic loads on bridges discretized as spatial and plane numerical models.
\end{abstract}

Keywords: train model, HSLM, dynamic factor, dynamic response, bridge, numerical model.

\section{INTRODUCTION}

Modelling and simulation of bridge behaviour under the effect of high speed train loads have become an important issue from the point of view of the applicable requirements for structures carrying high speed railway lines. The current regulations [3, 14, 16, 18, 19] require, for both new built and upgraded structures besides solving the eigenproblem (modal analysis) also carrying out

\footnotetext{
${ }^{1}$ DSc., PhD., Eng., Warsaw University of Technology, Institute of Roads and Bridges, Al. Armii Ludowej 16, 00-637 Warsaw, Poland, e-mail: a.zbiciak@il.pw.edu.pl

${ }^{2}$ MSc., Eng., Warsaw University of Technology, Institute of Roads and Bridges, AI. Armii Ludowej 16, 00-637 Warsaw, Poland, e-mail: r.oleszek@il.pw.edu.pl

${ }^{3}$ MSc., Eng., Warsaw University of Technology, Institute of Roads and Bridges, Al. Armii Ludowej 16, 00-637 Warsaw, Poland, e-mail: r.michalczyk@il.pw.edu.pl
} 
computations of the structure's dynamic response to railway loads (transient analysis). Such analyses are necessary since quasi-static methods do not allow predicting the resonance effects induced by trains travelling at a high speed.

There is a vast body of scientific literature on the problem of moving loads on elastic beams and decks (see studies $[4,5,11,13,17,21]$ and research reports [1,23]). These issues appear in analysing the bridge structure dynamics and stress behaviour of railway roadways and highway pavements which additionally consider discrete and continuum models of their subgrades - layers which provide support to the load deck support structures. These analyses consider inertial or massless forces, both concentrated and distributed. More advanced programs consider loads in the form of moving oscillators.

In the case of transient analyses the exact formulas known from the dynamic structural analyses are limited to simple structure models and relatively simple load cases $[6,15]$. In real superstructures numerical methods must be used to solve the equations of motion, due to complexity of high speed loading models defined by the relevant standards. Simulation of a moving load which is cyclical and variable in time is a key challenge here and, besides, the spacing of bogie axles is not always regular. Formulating of fundamental tasks in the dynamics of railway bridges under the high speed train load involves developing physical and mathematical models of the bridge-track-train (BTT) system taking into account interaction between the system components $[6,18,20,21]$. Current European (EN) standards allow making certain simplifications $[12,16]$. They result from lack of information on the dynamic behaviour of rail vehicles which could be obtained only during physical tests of real trains rather than on the basis of "model" trains represented in the standards.

\section{Approach to Dynamic Problems in the CurRent Standards}

\subsection{The SCope OF Dynamic ANalyses ACCORDing TO THE EUROPEAN (EN) STANDARDS}

The relevant EN standards [12], based on Eurocodes, define the rules for considering the dynamic effects of passenger trains loading which become important at the maximum allowed rolling stock speed of $350 \mathrm{~km} / \mathrm{h}$. Compared to the previously applied Polish Standards they represent a more extensive approach to railway bridges dynamic behaviour problems. There are two ways to allow for the dynamic character of loading: 
- by carrying out static load calculations using loads increased by application of dynamic coefficient $\varphi-$ as in previously applied local standards,

- by directly analysing the strains processes and distribution of internal forces and stresses generated by loads moving at specified speed on the basis of the dynamic response of the system (transient analysis).

In structures designed to carry high speed rail traffic of $v>160 \mathrm{~km} / \mathrm{h}$ it can happen that the dynamic amplification factor adopted on the basis of the formulas given in the standards will fail to cover the entire increase of internal forces, stresses and strains created by high-speed trains, which are cyclic in nature, resembling harmonic excitation. However, the current regulations do not require such advanced dynamic response analyses to be carried out in each and every case. In the case of many different structures located on lines with up to $v=200 \mathrm{~km} / \mathrm{h}$ maximum line speed the scope may be reduced to modal (eigenvalue) analysis. Skipping the dynamic response analysis is allowed only in the case of relatively simple structures exhibiting the behaviour of a simple longitudinal beam or a straight slab.

The European standard [12] provides a flow chart for determining the requirement for advanced dynamic analysis (determining the structure response - transient analysis) in the case of typical, relatively simple bridge structures carrying lines with up to $200 \mathrm{~km} / \mathrm{h}$ maximum (nominal) line speed. For maximum line speeds of $v>200 \mathrm{~km} / \mathrm{h}$ such analyses are obligatory.

In the dynamic analyses of rail bridges as per the requirements of the current standards $[3,16$, 18, 19] and Eurocode guidelines [12] it is required to:

- determine the main dynamic properties of the structure (natural frequency values and mode shapes ) through modal analysis,

- determine the dynamic response of the structure to the external excitation force imposed by standard trains (transient analysis),

- verify the results of static analysis for loads adjusted with dynamic amplification factor against the dynamic analysis output (dynamic structural response) to determine the dynamic increment $\varphi_{d y n}^{\prime}$ and assess the actual factor value,

- check if the load imposed by the movement of real trains or HSLM-A3 or HSLM-B train models does not generate, for different running speeds, internal forces at the levels exceeding those obtained in the static loading model LM-71 with loads adjusted by application of the dynamic amplification factor $\varphi$, 
- check the maximum accelerations $a_{z}$ at any point of the structure resulting in instability of the track and ballast and accelerations $b_{y}$ and deflections of the bridge spans $\delta$ affecting the comfort of travel for specific running speeds.

One of the most important requirements of EN [12] is the requirement to verify the dynamic analysis output against the static analysis output. This usually involves determining the actual dynamic amplification factor and dynamic increment (enhancement) $\varphi_{d y n}^{\prime}$ defined by the ratio between external loads or displacements determining the dynamic response of the structure to the adopted dynamic factors, as calculated from empirical equations $-\Phi_{2}$ or $\Phi_{3}$. The dynamic increment is defined as the maximum ratio between dynamic response $y_{d y n}$ (such as deflection) to the corresponding maximum static response $y_{\text {stat }}$, to loading with High Speed Load Model (HSLM) at any point of the structure.

$$
\varphi_{d y n}^{\prime}=\max \left|y_{d y n} / y_{s t a t}\right|-1
$$

This comparison requires carrying out of an additional static analysis of the structure and dynamic analysis for HSLM trains and selected Real Trains. The dynamic amplification factors, which are a function of the structural span length and are applied to increase the impact of load models LM71, SW/0 and SW/2 which are used in static analyses, are taken as the greater of the two values $\Phi_{2}$ and $\Phi_{3}$, calculated depending on the quality of track maintenance:

for carefully maintained track $(3.6 \mathrm{~m} \leq L \leq 65.0 \mathrm{~m})$ :

$$
\Phi_{2}=\frac{1.44}{\sqrt{L_{\Phi}}-0.2}+0.82 \text { with } 1.0 \leq \Phi_{2} \leq 1.67
$$

for track with standard maintenance (case recommended by EN-1991):

$$
\Phi_{3}=\frac{2.16}{\sqrt{L_{\Phi}}-0.2}+0.73 \text { with } 1.0 \leq \Phi_{3} \leq 2.0
$$

In the above equations $L_{\Phi}$ is the determinant length, i.e. the equivalent design span of any structural component with different support cases, reduced to the length of span of a simple beam. The real dynamic overload factor is determined with numerical methods based on integration of the equations of motion under 
HSLM-A or HSLM-B train load. In the case of arch bridges and concrete bridges of all types with a cover of more than $1.0 \mathrm{~m}$ the dynamic amplification factor may be reduced as follows:

$$
\Phi_{2,3}^{r e d}=\Phi_{2,3}-\frac{h-1.0}{10} \geq 1.0
$$

where: $h$-thickness of cover and ballast from the deck surface to the top of sleepers.

EN-1991 gives the following formula for calculating the natural frequency of simply supported bridges subjected to bending only:

$$
n_{0}=\frac{17.75}{\sqrt{\delta_{0}}}[\mathrm{~Hz}]
$$

where: $\delta_{0}[\mathrm{~mm}]$ - midspan deflection under fixed load; in concrete bridges the static modulus of concrete should be taken according to the load application duration corresponding to the natural frequency of the bridge. In the case of bridges carrying lines with up to $200 \mathrm{~km} / \mathrm{h}$ maximum line speed the dynamic analysis may be reduced to solving the eigenvalue problem. The first natural frequency $n_{0}$ calculated with equation (2.5) should be within the limits calculated as follows:

upper limit related to the irregularity of track:

$$
n_{0}=94.76 \cdot L^{-0.748}[\mathrm{~Hz}]
$$

lower limit related to dynamic impact of trains.

$$
\begin{gathered}
n_{0}=80 \cdot L^{-1}[\mathrm{~Hz}] \text { for } 4 \mathrm{~m} \leq L_{\Phi} \leq 20 \mathrm{~m} \\
n_{0}=23.58 \cdot L^{-0.592}[\mathrm{~Hz}] \text { for } 20 \mathrm{~m} \leq L_{\Phi} \leq 100 \mathrm{~m}
\end{gathered}
$$

\subsection{Mechanical Models of RaIl Vehicles in Relation to the EN-1991 ReQuirements}

There are various representations of moving rail vehicles used in dynamic analyses, differing in terms of mathematical and physical accuracy $[2,6,7,8,9,12,16]$. The most popular models are (Fig. 1):

- point load of constant value moving uniformly along a beam (1),

- point mass moving uniformly along a beam (2), 
- viscoelastic one- or two-mass oscillator (3) moving uniformly along a beam in which aggregated point masses represent the total weight of vehicle or of the wheel set and vehicle body respectively and the visco-elastic properties are represented by spring stiffness and spring damping ratio ,

- spatial or plane model of multiple-mass dynamic assembly with multi-stage springing and damping (4),

- assumed mechanical model of rail vehicle with multiple degrees of freedom (5) in which the respective components (bogies, wheels, horizontal and vertical springs, body, dampers, motor) are represented by concentrated weight solids tied by viscoelastic joints, rods, plates and solids.

The first two models can be used for determining the dynamic response of bridge yet without analysing the behaviour of vehicle and vehicle-structure interaction. These representations do not include springing model. This interaction can be simulated with oscillator models (concentrated masses with viscoelastic ties).
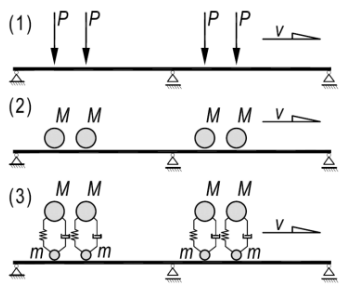
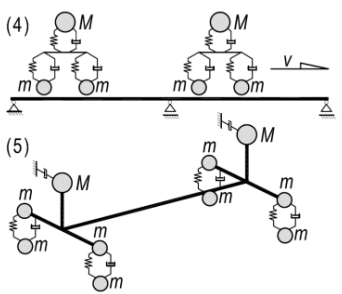

Fig. 1. Rail vehicle models used in dynamic analyses

Taking into account the real-life geometry and spacing of axles of rail vehicles including power car (locomotive) and coaches, as well as a considerable trainset length the moving load models used in railway analyses must have a cyclic structure. Moreover, equal spacing of axles and bogies over the whole trainset length could not be found in real life. This implies the need to simulate the loads as a set of concentrated loads, concentrated masses or oscillators moving on the structure. Another challenge is the need to have determined all the spring and damping parameters of real rail vehicles in order to subsequently apply them as inputs in the mechanical model. For this reason and due to the cost and time consuming modelling and computations the last two of the above-mentioned models can hardly be used in practical railway structure engineering. The European standards [12] include simplified representations in the form of sets of concentrated loads (load models). The types and parameters of trains which will ply the line are not known at the time when the bridges to carry the line are designed. 
The European standards [12] give the following classification of dynamic loads imposed on railway bridges by trains travelling at high speeds:

- real train models, types A-F - representing typical trains plying the railway lines in EU countries, provided that the relevant information on the trains which will be operated on the new or upgraded line can be obtained (used only sporadically),

- high-speed traffic models of HSLM-A and HSLM-B represent the dynamic load effects of articulated, conventional and regular high speed passenger trains in accordance with the requirements for the European Technical Specification for Interoperability. This concerns bridges designed for international lines for which the European high speed interoperability criteria are applied.

The High Speed Load Model comprises two independent families of universal trains designated HSLM-A and HSLM-B. These two load models differ in terms of coach length, number of intermediate passenger coaches, axle spacing of bogies and axle load (in the range 170-210 kN). In the case of HSLM-B (Fig. 2b) the concentrated loads spacing representing uniform axle load of 170 $\mathrm{kN}$ and the number of axles are related to the bridge span length (see nomograph in Fig. 2c [8]).

In the case of simple structures of simple span diagram exhibiting only linear dynamic behaviour of a straight beam and span length of it is allowed to use in the dynamic analysis a single HSLM-A universal train. The choice of critical (representative) train from the pre-defined trains A1-A10 is defined by the function of critical wavelength of excitation which is the function of the wavelength of excitation at maximum design speed (the wavelength of excitation value is obtained from the nomograph of the European standard [12]).
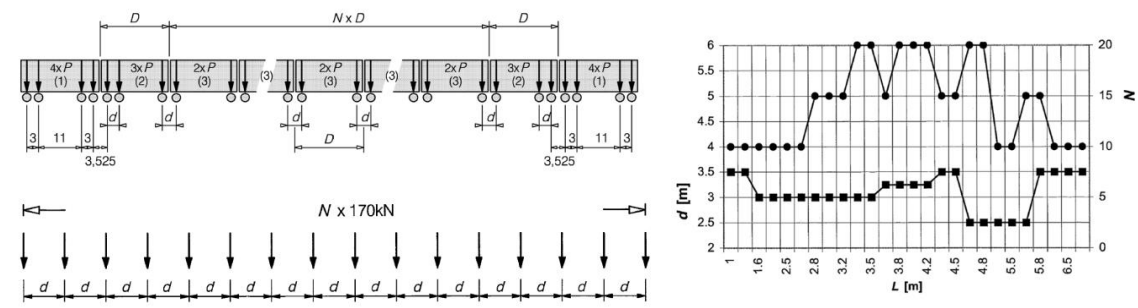

Fig. 2. Rail dynamic load diagram according to EN [12]: a) HSLM-A, b) HSLM-B, c) nomograph for determining the number of and spacing of axles of HSLM-B load model 
In the case of structurally challenging engineering cases (skew deck, high torsion loads imposed on the deck support structure, half-through construction, etc.), including bridges with decks continuous over supports and with $L<7.0 \mathrm{~m}$ it is recommended to carry out transient analysis for all the universal trains - from HSLM-A1 to HSLM-A10. Moreover, in the case of complex structures featuring higher mode shapes of natural frequencies of deck, with half-through or through construction it is recommended to include in the analysis also HSLM-B trains.

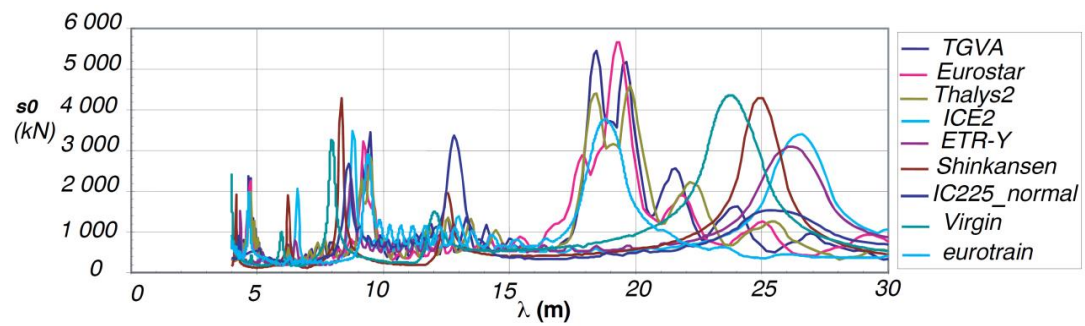

Fig. 3. Dynamic response curves of selected high-speed trains [18]

The HSLM model trains as defined in the European standards are load models only, which include the dynamic impacts of certain types of passenger trains in compliance with the criteria of Appendix $\mathrm{E}$ [12]. These criteria concern the maximum axle loads, bogie wheelset spacing, coach length, spacing between neighbouring bogies and maximum overall length of trainset. The actual dynamic response of high-speed trains is determined using the Fourier series and extrapolation of frequency-domain responses [18]. They represent train induced dynamic excitation options and are independent of the structure performance. The dynamic performance depends solely on the load and may be described by the following equation (excitation wavelength $\lambda=v / n_{0}$ ):

$$
S_{0}(\lambda)=\sqrt{\left[\sum_{i} P_{i} \sin \left(2 \pi \frac{d_{i}}{\lambda}\right)\right]^{2}+\left[\sum_{i} P_{i} \cos \left(2 \pi \frac{d_{i}}{\lambda}\right)\right]^{2}}
$$

In the case of bridges designed with the use of HSLM load models the European standards to not require carrying out dynamic analyses with real high-speed trains, whose dynamic impacts should be covered by the standard load models. The dynamic parameters of real trains are useful for quickly comparing the dynamic impacts of different trains. The selected response spectra of the most popular high-speed trains (TGV, Eurostar, ICE2, ETR, etc.) are presented in Fig. 3. 


\section{APPROACH TO DYNAMIC PROBLEMS IN THE CURRENT STANDARDS}

This research concerns a railway bridge having a typical structure, commonly designed at the time of rapid development of the railway network in the 1970s which is an option of choice also in the present times. This structure corresponds to class $\alpha_{k}=1.21$ as per EN-1191. The standard dynamic amplification factor of the deck is $\Phi_{2}=1.126$ for careful maintenance and $\Phi_{3}=1.190$ for standard maintenance of the track.

The deck support structure comprises two plate girders of wide flange beam cross-section and orthotropic deck of steel class S275 $\left(\gamma_{s}=78.5 \mathrm{kN} / \mathrm{m}^{3}, E_{s}=205 \mathrm{GPa}\right)$. The main plate girders are spaced at $3.35 \mathrm{~m}$, measuring at the underside of structure. From the geometric point of view one plate girder is built of inclined web of $1680 \times 15 \mathrm{~mm}$, top flange of $290 \times 30 \mathrm{~mm}, 340 \times 30 \mathrm{~mm}, 390 \times 30 \mathrm{~mm}$ and $440 \times 30 \mathrm{~mm}$ plates (stepped fishplate arrangement) and lower flange of $390 \times 30 \mathrm{~mm}$ and $440 \times 30$ $\mathrm{mm}$ plates. The girders are braced in the transverse direction with $374 \mathrm{~mm}$ deep plate crossbeams placed at $2.0 \mathrm{~m}$ centres over the bridge length. The crossbeams have lower flange of $220 \times 20 \mathrm{~mm}$ in size while the $12 \mathrm{~mm}$ thick upper flange is the bearing plate of the ballast pan (mechanically interacting component of the section).

The ballast pan sides are made of $15 \mathrm{~mm}$ plate, installed between the main plate girders on the entire length of bridge, which are structurally coupled with the main girders (included in the cross-section during design calculations). The orthotropic slab has rectangular plate ribs of $240 \times 25 \mathrm{~mm}$ in size, placed at 0.50 centres. The structure has a design span of an simple beam structure. The roadway comprises UIC 60 running rails and guardrails, pre-tensioned sleepers and crushed stone ballast. There is a maintenance walkway on one side of the bridge.

\section{DESCRIPTION OF NUMERICAL SiMUlationS}

\subsection{GeNeral IDEA OF THE METHOD}

Vibration problems in systems involving vehicle-bridge interaction are an important part of dynamic analyses of railway bridges. From the point of view of the bridge engineer one of the primary issues is to determine the stress status of the load-bearing components with undefined behaviour of the railway vehicle. For this purpose discrete-continuous models of bridge decks are used, in which the girder or deck is modelled as a continuous system described by partial differential equations while the train or a single axle is represented by a discrete oscillator model [21]. The problem of vibrations 
in a system of this type requires application of discretization procedure in relation to spatial variables using, for example, the Finite Elements Method (FEM) or Finite Difference Method (FDM). In this way we obtain a coupled set of ordinary differential equations which can be solved by employing one of the available methods, including, without limitation, central differences method, Newmark method, Runge-Kutta method, etc. [6,9].

The current FEM systems allow to build complex computational models with multiple degrees of freedom. These systems allow for using different types of elements (truss, rod, beam, plate, shell, solid), different degree of displacement field approximation (for example linear or quadratic), different kinematic connections between nodes of numerical structures (for example elastic, viscoelastic) and different elements, such as springs and dampers of defined performances. Thus, in the present times it is possible to obtain a true representation of the bridge structure including the effect of the ballast and track performance. The fundamental part of the analysis of the dynamic response of structure is to correctly define the function of moving load in relation to time and speed of travel, i.e. determining the load distribution on the model elements as a function of time variable. As a consequence the motion equation (4.1) describing the relationship between stiffness, inertia, damping and loading of the structure is represented by recurrence relations. This issue is dealt with in the further part of this paper.

Many commercially available FEM systems have implemented the Newmark algorithm of direct integration of motion equations (step-by-step integration method). It is a numerical method for solving known equilibrium equations in dynamic analyses.

$$
\mathbf{M} \ddot{\mathbf{u}}(t)+\mathbf{C u}(t)+\mathbf{K u}(t)=\mathbf{p}(t)
$$

where: $\mathbf{M}$ - mass matrix, $\mathbf{C}$ - damping matrix, $\mathbf{K}$ - stiffness matrix, $\mathbf{p}$ - vector of time-varying force, $\mathbf{u}-$ total displacement vector.

Modal damping (mass- and stiffness-proportional damping, a.k.a. Rayleigh damping) is the type of damping (damping matrix) commonly applied in dynamic analyses. This means that the damping matrix $\mathbf{C}$ is made by combining the mass matrix $\mathbf{M}$ and the stiffness matrix $\mathbf{K}$ at specific proportions according to the following formula:

$$
\mathbf{C}=\alpha \mathbf{M}+\beta \mathbf{K}
$$


where: $\alpha, \beta$-coefficients of proportionality of internal and external damping calculated according to the percentages of the respective free vibration mode shapes and frequencies and the damping ratio value.

\subsection{Numerical Model of the Analysed Structure}

In order to limit the size of numerical problem the structure was modelled by a beam system in three dimensional space following the approach adopted in [20, 21, 22]. Beam elements used for discretizing the structure were one-dimensional, two joint rods with the field of displacement approximated with linear shape functions.

Beam models by their very nature do not include ribs, crossbeams and other secondary structural components with typically very high frequency of vibrations. However, due to the nature of dynamic loads, the adopted representation takes into account the weight of such components, as well as the weights of ballast, tracks and equipment. Detailed determination of the effect of sprung mass interaction with the approach slab and with the bridge spans was omitted as allowed by the European standard [12] This effect was taken into account in a simplified manner as for bridge spans of $L<30.0 \mathrm{~m}$ by increasing the lower structural damping value $\zeta=0.5 \%$ with supplemental damping value of $\Delta \zeta=0.09 \%$. Mass- and stiffness-proportional (Reylaigh) damping model was applied. The time step was $\Delta t=0.01 \mathrm{sec}$.

\subsection{LOAD MODEL}

In order to determine the dynamic response of the system to the load imposed by a high-speed train according to the European standard a bespoke dynamic load model was developed using the tools of the FEM Abaqus computer program. The load continuous over time was converted to a set of concentrated forces acting at the joints of the numerical model.

The load was applied as sets of concentrated loads simulating the action of HSLM train models $\mathrm{A} 1-\mathrm{A} 10$ [12]. The analysis is based on running speed of $v=200 \mathrm{~km} / \mathrm{h}, v=350 \mathrm{~km} / \mathrm{h}$ and includes static loading case as a control.

\section{Selected Calculation Results}

The outputs of dynamic analysis (modal and transient) are presented as time-history diagrams of certain parameters (displacement $u_{z}$, acceleration $a_{z}$, midspan bending moments $M_{y \max }$ ) (see. Figs. 4-6). Comparison of the highest deflections of span loaded with HSLM-A8 train travelling at different 
speeds. From the point of view of the guidance provided by the standards it is important to consider the curves of selected mechanical properties, such as vertical span acceleration $a_{z}$, span deflections $u_{z}$ or internal forces $(\mathrm{N}, \mathrm{M}, \mathrm{T})$ during the time of travel of HSLM train and after it has left the structure. This allows to investigate at what running speeds the dynamic excitation effects would exceed the maximum allowable values as given by the relevant standards and regulations $[12,16]$.

Fig. 4 presents the time-history curve of midspan deflections $u_{z}$, which, when exceeded - at the train speeds defined in the European standards - may affect the comfort of passengers. The deflections caused by HSLM-A8 train at three different speeds were compared: static load (control), $200 \mathrm{~km} / \mathrm{h}$, $350 \mathrm{~km} / \mathrm{h}$. Only small differences were noted between the static load case and loading with train travelling at $v=200 \mathrm{~km} / \mathrm{h}$. Conversely, considerable differences (ca. 26\%) were noted in the case of $v=350 \mathrm{~km} / \mathrm{h}$ train speed.

Fig. 5 presents the time-history curve of midspan acceleration $a_{z}$ of the bridge when dynamically loaded with HSLM-A8 train. It has been noted that the accelerations exceed the maximum allowable value $[12,16,18,19]$ by ca. $40 \%$ due to stability of rail ballast $a_{z \max }=3.5 \mathrm{~m} / \mathrm{sec}^{2}$ by ca. $40 \%$.

Fig. 6 presents the time history curve of dynamic midspan moment of bridge loaded with HSLM-A8 train. The $M_{y \max }(t)$ curves allow comparing the dynamic moment with the static load movement, which is used as the basis of evaluating the stress state of the structure loaded by rail traffic according to the European standards. Similarly to deflections, also the midspan bending moments are much higher for the running speed of $v=350 \mathrm{~km} / \mathrm{h}$ with the differences reaching up to ca. $56 \%$.

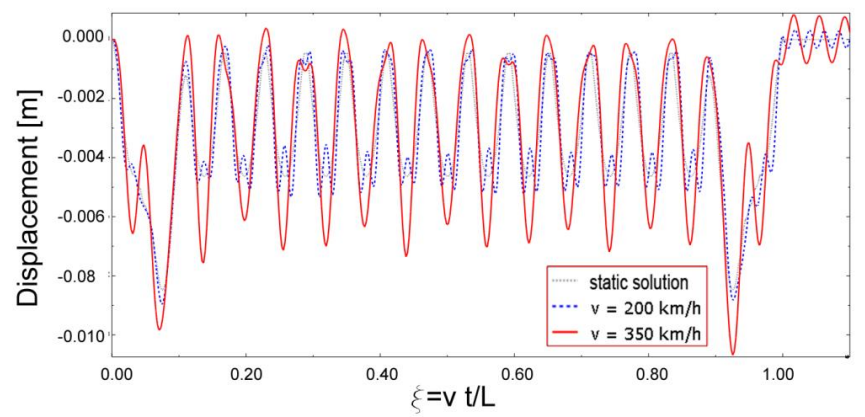

Fig. 4. Examples of time-history curves for loading with HSLM-A8 train: midspan deflection 


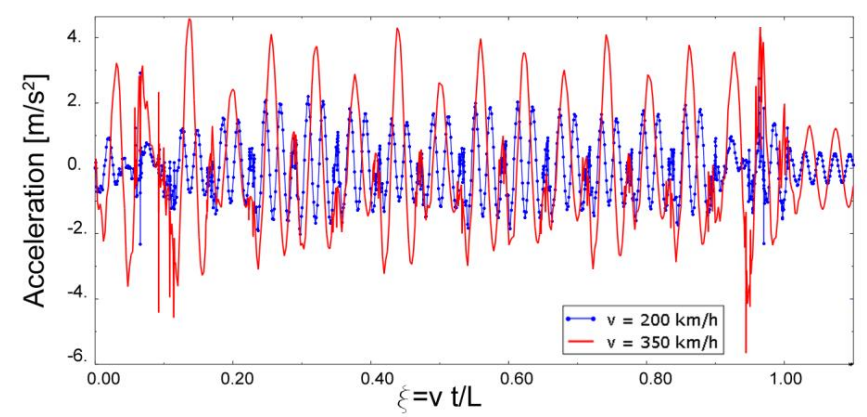

Fig. 5. Examples of time-history curves for loading with HSLM-A8 train: midspan acceleration

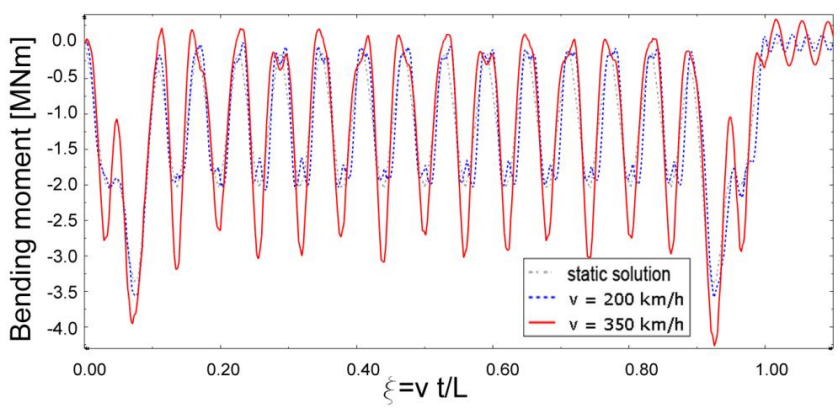

Fig. 6. Examples of time-history curves for loading with HSLM-A8 train: midspan bending moment

Taking the curve in Fig. 4 to compare the midspan deflections $u_{z}(t)$ at $v=350 \mathrm{~km} / \mathrm{h}$ train speed with the static load case it is possible to calculate the real dynamic amplification factor. The maximum dynamic response $u_{z \max }$ is ca. $7.2 \mathrm{~mm}$ as compared to the static load value $u_{z s t a t}$ of ca. $4.6 \mathrm{~mm}$. This yields the dynamic increment $\varphi_{d y n}^{\prime}$ of ca. 0.565. The real dynamic amplification factor $\varphi$ is ca. 1.56 which is by $31 \%$ higher than the standard value of $\Phi_{3}=1.19$ for track with standard maintenance. At train speed of $v=200 \mathrm{~km} / \mathrm{h}$ the dynamic deflections are comparable to the deflections obtained in the static load case. Thus it is considered safe and appropriate to apply the standard values of the dynamic amplification factors at that speed. 


\section{Conclusion}

This paper presents some aspects of numerical simulation of the interaction of a railway bridge of typical steel structures and with high-speed trains travelling on them using the load models defined by the current European standards [12] and recommended by the Polish railway guidelines [3, 16]. The current standard requirements are referred to, in which the computer computations of dynamic response are the basis for assessing the suitability of structure for high speed rail traffic $(v>160 \mathrm{~km} / \mathrm{h}$ ). Example calculations are presented in this paper, in which moving load generation is done with the method developed by the authors with the use of FEM Abaqus software. The calculations demonstrate that higher running speeds generate greater displacements, accelerations and internal forces. Some of the above-mentioned parameters may even exceed the maximum allowable standards as per the relevant standards. Considerable dynamic effects are observed in the deck support structure already at $200 \mathrm{~km} / \mathrm{h}$. At higher speeds the deflections, accelerations and internal forces increase considerably.

Attention is drawn to the fact that most of the commercially available FEM codes (including Abaqus) do not have moving (traffic) loads implemented in the load defining modules. With the approach, conceived by the authors of this paper, it was possible to demonstrate that such analyses are adequate and useful in the design of new and upgraded structures in compliance with the currently binding requirements. The authors plan to continue their work and modify the above-presented moving load generation technique to enable its application in solving the vibration problems in bridges modelled as spatial and plane structures. 


\section{REFERENCES}

1. European Rail Research Institute, (2000), Rail Bridges for Speeds $>200 \mathrm{~km} / \mathrm{h}$ - Final Report, D214FM997691ERPA.DOC/01.

2. L. L. Humar, A. M. Kashif, "Dynamic response of bridges under travelling loads”, Can. J. Civ. Eng., 20:287298, 1993.

3. Id-2 Design guidelines for the railway engineering structures (in Polish). PKP-PLK S.A., Schedule to the Regulation No. 29/2005 by the PKP-PLK S.A. Management Board of 18th May 2015.

4. H. H. Jeffcott, "On the vibrations of beams under the action of moving loads", Phil.Magazine, 8(48):66-97. Ser. 7, 1929.

5. M. Klasztorny, „Dynamics of Beam Bridges Loaded by High-Speed Trains”, WNT, Warsaw, 2005

6. J. Langer, "Dynamics of structures" (in Polish), Wrocław University of Technology Publishing House, Wrocław, 1980 .

7. M. Majka, M. Hartnett, "Effect of speed, load and damping on the dynamic response of railway bridges and vehicles", Computers and Structures, 86:556-572, 2008.

8. M. Majka, M. Hartnett, "Dynamic response of bridges to moving trains: A study on effects of random track irregularities and bridge skewness", Computers \& Structures, 87(19-20):1233-1252, 2009.

9. M. Olsson, "Finite element, modal co-ordinate analysis of structures subjected to moving loads", Journal of Sound and Vibration 99(1) (1985), 1-12.

10. P. Paultre, O. Chaallal, J. Proulx, "Bridge dynamics and dynamic amplification factors - a review of analytical experimental findings", Can. J. Civ. Eng., 19:260-278, 1992.

11. A. Pipinato, "Moving loads bridge response: Structural analysis and eurocode provisions", Advanced Materials Research. Vol. 629. 2013.

12. PN-EN 1991-2:2007 Actions on structures. Part 2: Traffic loads on bridges, PKN, Warsaw .

13. F. S. Samani, F. Pellicano, "Vibration reduction on beams subjected to moving loads using linear and nonlinear dynamic absorbers", Journal of Sound and Vibration, 325:742-754, 2009.

14. SB-LRA (2007). Guideline for Load and Resistance Assessment of European Railway Bridges - Advices on the use of advanced methods. Prepared by Sustainable Bridges - a project within EU FP6.

15. K. Sturzbecher, "Dynamic analysis of railroad bridge concrete encased girder spans under the loads with 250 $350 \mathrm{~km} / \mathrm{h}$ traffic speeds", Archives of the Institute of Civil Engineering of the Poznan University of Technology No. 4/2008, Poznań 2008

16. Technical standards - Specific design guidelines for modernisation or construction of railway lines up to maximum speed vmax $\leq 200 \mathrm{~km} / \mathrm{h}$ (for conventional rolling stock) and $250 \mathrm{~km} / \mathrm{h}$ (for tilting rolling stock). PKP PLK S.A., 14/06/2010]

17. S. P. Timoshenko, "On the forced vibrations of bridges", Phil.Magazine, 43:1018-1019. Ser. 6, 1922.

18. UIC CODE 776-2. Design requirements for rail-bridges based on interaction phenomena between train, track and bridge. International Union of Railways, June 2009.

19. Union Internationale des Chemins de Fer, (2003), UIC Code - Design requirements for rail-bridges based on interaction phenomena between train, track, bridge and in particular, speed.

20. H. Xia, N. Zhang, G. de Roeck, "Dynamic analysis of high speed railway bridge under articulated trains, Computer and Structures, 81 (2003) 2467-2478.

21. A. Zbiciak, M. Ataman, "Dynamic analysis of a discrete-continuum system of the vehicle-beam using Simulink software" (in Polish). Theoretical Foundations of Civil Engineering, Publishing House of the Warsaw University of Technology, Warsaw, 2008, pp. 377-382.

22. H. Zobel, A. Zbiciak, R. Oleszek, R. Michalczyk, P. Mossakowski, "Numerical identification of the dynamic characteristics of a steel-concrete railway bridge", Roads and Bridges 2014(13), pp. 275-301

23. K. Żółtowski, A. Madaj et al., "Modernisation of the railroad bridge over the Pilica river with upgrading to highspeed train traffic”, AIIL 4/2010, Poznań University of Technology Publishing House, Poznań 2010, pp. 289299.

Received 09. 02. 2016

Revised 06.03. 2016 


\section{LIST OF FIGURES AND TABLES:}

Fig. 1. Rail vehicle models used in dynamic analyses

Rys. 1. Modele taboru kolejowego stosowane w analizach dynamicznych

Fig. 2. Rail dynamic load diagram according to PN-EN: a) HSLM-A, b) HSLM-B, c) nomograph for determining the number of and spacing of axles of HSLM-B load model

Rys. 2. Schemat dynamicznego obciążenia kolejowego według PN-EN [8]: a) model pociągu HSLM-A, b)

Fig. 3. Dynamic response curves of selected high-speed trains ls used in dynamic analyses

Rys. 3. Charakterystyki dynamiczne wybranych pociągów szybkobieżnych

Fig. 4. Examples of time-history curves for loading with HSLM-A8 train: midspan deflection

Rys. 4. Przykładowe przebiegi czasowe dla przejazdu pociągu HSLM-A8: ugięcie środka przęsła

Fig. 5. Examples of time-history curves for loading with HSLM-A8 train: midspan acceleration

Rys. 5. Przykładowe przebiegi czasowe dla przejazdu pociągu HSLM-A8: przyspieszenie środka przęsła

Fig. 6. Examples of time-history curves for loading with HSLM-A8 train: midspan bending moment

Rys. 6. Przykładowe przebiegi czasowe dla przejazdu pociągu HSLM-A8: momenty zginające w środku przęsła 


\section{DYNAMIKA ORTOTROPOWEGO MOSTU KOLEJOWEGO W ŚWIETLE NORM PN-EN}

Słowa kluczowe: modele pociągów, HSLM, współczynnik dynamiczny, odpowiedź dynamiczna, most, model numeryczny.

\section{STRESZCZENIE:}

Zagadnienia modelowania i symulacji mostów obciążonych pociągami szybkobieżnymi są istotne w świetle obowiązujących wymagań dotyczących obiektów inżynieryjnych na liniach kolejowych dużych prędkości. W konstrukcjach nowoprojektowanych lub przystosowywanych do nowych warunków eksploatacji, współczesne przepisy, oprócz rozwiązania zagadnienia własnego (analiza modalna), wymagają wykonania obliczeń dynamicznej odpowiedzi ustroju na obciążenia kolejowe (tzw. analiza czasowa). Analizy tego typu są konieczne, gdyż metody quasi-statyczne nie dają możliwości przewidywania skutków rezonansowych wywołanych pociągami poruszającymi się z dużymi prędkościami.

W pracy przedstawiono pokrótce literaturę dotyczącą problematyki ruchomych obciążeń. Zagadnienia sprężystych belek i płyt są wykorzystywane w dynamice konstrukcji mostowych, a także w szacowaniu wytężenia nawierzchni kolejowych i drogowych, gdzie dodatkowo uwzględnia się dyskretne lub ciągłe modele podłoża, na których spoczywają wymienione elementy konstrukcyjne, przenoszące obciążenia. Rozpatrywane są siły o charakterze inercyjnym albo bezmasowym, zarówno skupione jak i rozłożone. Bardziej zaawansowane aplikacje dotyczą obciążeń w postaci ruchomych oscylatorów. W przypadku analiz czasowych wzory ścisłe znane z dynamiki budowli dotyczą elementarnych modeli konstrukcji i nieskomplikowanych schematów obciążeń. W realnych ustrojach, z uwagi na złożoność normowych modeli obciążeń pociągami dużych prędkości, do rozwiązania równań ruchu niezbędne są metody numeryczne. Przedstawiono sformułowanie podstawowych zadań w dynamice mostów kolejowych, obciążonych pociągami szybkobieżnymi oraz zasady opracowywania modeli fizycznych i matematycznych układu most-tor-pociąg (MTP), w którym uwzględnia się interakcję jego składników. W tym zakresie współczesne normy PN-EN dopuszczają pewne uproszczenia, które wynikają z trudności w określaniu dokładnych charakterystyk dynamicznych pojazdów szynowych.

Omówiono pokrótce zawarte w obowiązujących normach PN-EN reguły, dotyczące uwzględnienia efektów dynamicznych od pociągów pasażerskich. Dynamiczny charakter obciążenia jest uwzględniany poprzez przeprowadzenie obliczeń statycznych na zwiększonych przez współczynnik dynamiczny obciążeniach lub na podstawie dynamicznej odpowiedzi układu (analiza czasowa). Nie w każdym przypadku obecne przepisy wymagają zaawansowanych obliczeń dynamicznej odpowiedzi konstrukcji mostowej. Może się zdarzyć jednak sytuacja, że współczynnik dynamiczny założony z góry na podstawie wzorów normowych, nie obejmie całego przyrostu sił wewnętrznych, naprężeń czy odkształceń wywołanych obciążeniem pociągiem dużych prędkości, które w tych warunkach ma charakter cykliczny zbliżony do wymuszenia harmonicznego.

Jednym z istotniejszych wymagań postawionych przez PN-EN jest konfrontacja wyników analizy dynamicznej odpowiedzi konstrukcji z wynikami analizy statycznej. Porównanie to zwykle obejmuje wyznaczenie rzeczywistego współczynnika dynamicznego do współczynników dynamicznych założonych a’priori wyznaczonych z wzorów empirycznych. Porównanie to wymaga wykonania dodatkowej analizy statycznej konstrukcji i analizy dynamicznej dla pociągów z grupy HSLM oraz wybranych ,pociągów rzeczywistych”.

W referacie przedstawiono wybrane aspekty symulacji numerycznej zachowania stalowego mostu kolejowego o typowej konstrukcji pod obciążeniem pociągami dużych prędkości, zgodnie z modelami przedstawionymi w obowiązujących 
normach PN-EN i zalecanych przez wytyczne kolejowe. Obiekt mostowy poddany analizie odpowiada klasie mostów kolejowych, które wznoszono w okresie intensywnej budowy sieci kolejowej w latach 70-tych XX wieku. Z uwagi na ograniczenie rozmiaru zadania numerycznego model obliczeniowy konstrukcji przyjęto jako belkowy w przestrzeni trójwymiarowej. W celu wyznaczenia dynamicznej odpowiedzi układu na obciążenie wybranym na podstawie PN-EN pociągiem dużych prędkości opracowano, korzystając z narzędzi programistycznych systemu MES ABAQUS, indywidualny model obciążenia ruchomego. Dokonano przekształcenia obciążenia o ciągłym przebiegu czasowym na układ sił skupionych działających w węzłach modelu numerycznego. Model obciążenia przyjęto w postaci strumieni sił skupionych, symulujących oddziaływania pociągów modelowych HSLM-A1 $\div$ A10. W analizie uwzględniono prędkości ruchu v=200 km/h, v=350 km/h oraz jako referencyjny przypadek obciążenia statycznego.

Przedstawiono przykład obliczeń z wykorzystaniem autorskiej metody generowania obciążeń ruchomych. Wykonane obliczenia wykazały, że w obiekcie wraz ze wzrostem prędkości ruchu, przemieszczenia, przyspieszenia oraz siły wewnętrzne wzrastają. Niektóre z wymienionych wielkości mogą nawet przekraczać wartości dopuszczalne określone w normach. Zwiększone efekty dynamiczne pojawiają się w ustroju nośnym mostu już przy prędkości $\mathrm{v} \approx 200 \mathrm{~km} / \mathrm{h}$. Prędkości większe powodują znaczny wzrost ugięć, przyspieszeń oraz sił wewnętrznych.

Należy wyraźnie podkreślić, iż w większości komercyjnych programów MES (w tym w programie ABAQUS), ruchome obciążenia nie są standardowo zaimplementowane w modułach odpowiedzialnych za definiowanie obciążeń. Autorskie podejście do tego zagadnienia pozwoliło na uzyskanie rezultatów potwierdzających jego adekwatność i przydatność tego typu analiz w projektowaniu i modernizacji konstrukcji mostowych w świetle współczesnych wymagań. W dalszej perspektywie autorzy opracowania planują przystosowanie niniejszego algorytmu generowania obciążeń ruchomych w zagadnieniach drgań mostów modelowanych jako ustroje przestrzenne i powierzchniowe. 